\title{
DRIVERS OF ECONOMIC PERFORMANCE: WHAT CAN WE OBSERVE IN THE CZECH FOOD INDUSTRY?
}

\author{
Gabriela Trnková1, Zdeňka Žáková Kroupová
}

\footnotetext{
1 University of Hradec Králové, Faculty of Informatics and Management, Department of Economics, Czech Republic, ORCID: 0000-0001-5181-5689, gabriela.trnkova@uhk.cz;

2 Czech University of Life Sciences Prague, Faculty of Economics and Management, Department of Economics, Czech Republic, ORCID: 0000-0001-5834-3338, kroupovaz@pef.czu.cz.
}

\begin{abstract}
This paper is focused on the investigation of the competitiveness drivers, namely technical and scale efficiency and technological change, and their relation to the profitability of the Czech food processing companies in the period 2016-2019. This investigation is based on the stochastic frontier modelling of an input distance function in the specification of the four-errorcomponent model. The model is estimated with a multi-step procedure employing the generalized method of moments estimator addressing the potential endogeneity of netputs, and panel data gained from the Bisnode Albertina database. The results revealed (evaluated on the sample mean) that investigated food processing sectors were scale efficient in the analysed period, however, their production technologies exhibited prevailing technological regress. Moreover, the room for almost $17 \%$ cost reduction by the technical efficiency improvements was found out in all investigated sectors. Although inter-sectoral differences exist in the scale efficiency, technological change and technical efficiency dynamics, to increase the productivity and competitiveness of food processing companies, it is generally appropriate to focus on technical efficiency and technological change improvements. Both these competitiveness drivers connected with the cost reduction and minimizing of wastage of inputs are achievable through innovations. In general, the basic source of their financing is profit, the achievement of which is supported by cost minimization. However, it was found that sub-sectors, which are linked to sensitive sectors of agricultural production that means sectors with the lowest national self-sufficiency, the highest level of imports and thus strong cost reduction pressure - have problem to translate the ability to produce efficiently into profitability. Although these food sectors, which have been also facing strong competition for a long time, which leads to significant pressure to reduce costs, achieved the highest technical efficiency, their profitability was lowest from the investigated sectors.
\end{abstract}

Keywords: Stochastic frontier analysis, technical efficiency, profitability, food processing industry, the Czech Republic.

JEL Classification: D24, L66.

APA Style Citation: Trnková, G., \& Žáková Kroupová, Z. (2021). Drivers of Economic Performance: What Can We Observe in the Czech Food Industry? E\&M Economics and Management, 24(3), 110-127. https://doi.org/10.15240/tul/001/2021-03-007

\section{Introduction}

The production of food products is one of the strategic branches of the manufacturing industry, as it supplies food to the market and thus ensures the diet of the population. In 2018, based on data from the Ministry of Industry and Trade (MPO, 2019), the food industry accounted for $5.4 \%$ of the total value added of the manufacturing industry. Furthermore, $7.6 \%$ of employees in the total number of manufacturing industry workers demonstrate social importance, however, with a significant 
wage disparity compared to other sectors of the manufacturing industry. The business structure of the Czech food industry is represented mainly by small and medium-sized enterprises and so the importance of this sector is also irreplaceable from rural development point of vies. However, in a strong competitive environment, more and more production concentration and at the same time specialization are manifested. Mezera et al. (2019) state, that foreign capital enters just sub-sectors with sufficient quality raw materials and companies with concentration production and thus with necessary capacities, and they mention the dairy industry as an example.

With the accession of the Czech Republic to the EU, the Czech food industry is facing much greater competitive pressure than in the past, which requires producers to operate more efficiently and innovatively. Blažková and Dvouletý (2019) mention some of the challenges facing the Czech food industry, especially lack of technological capabilities and managerial skills, high corporate indebtedness, and disadvantageous market position against retail. The overcrowded retail network in the Czech Republic (after the entry of large multinational chains into the Czech retail market) distorts the natural competitive environment and forces traders to assert themselves on price, which leads primarily to a reduction in production costs for their suppliers (MPO, 2019). All these problems have affected the efficiency and profitability and thus the competitiveness of not only the food industry but the whole agri-food sector as well.

Therefore, this study investigates the basic prerequisites of competitiveness - technical and scale efficiency and technological change and examines if these drivers are translated into a better competitive position and thus into higher profitability. The partial goals of this paper are as follows:

1. measure and compare the returns to scale, technological change, and technical efficiency for the Czech food industry and its particular sub-sectors;

2. examine the relationship between these drivers and profitability.

In the following section, we briefly introduce the theoretical background of our research. Further, the model and estimation strategy are described, and then dataset and variables are introduced. The next part is dedicated to the interpretation of the obtained results. Finally, some conclusions summarizing the main findings and implications are drawn.

\section{Theoretical Background}

Economic performance is usually viewed in terms of profitability, productivity, and efficiency. Efficiency is a multi-faceted phenomenon. Generally speaking, it indicates whether a firm is able to use the existing technology in the best way (Latruffe, 2010). In output orientation, it refers to the firm's ability to produce the optimal quantities of output in a certain technological regime (environment) and at given input quantities. In input orientation, it represents the firm's ability to produce a given level of output in a certain technological regime using the minimum quantity of inputs (Dimara et al., 2008). Economic theory distinguishes technical efficiency that refers to the firm's ability to minimize input use in the production of a given output vector, or the ability to obtain maximum output from a given input vector (Kumbhakar \& Knox Lovell, 2000); scale efficiency that gives insights into whether the firm operates at the most productive scale size where the average productivity reaches a maximum level (Kounetas \& Tsekouras, 2007); and allocative efficiency that is linked to the ability of a firm to produce at a given level of output using inputs in their optimal proportions given their respective prices, or to produce an optimal combination of outputs given their respective prices (Farrell, 1957). Obviously, technical and scale efficiency refers to a physical notion, independent of input and output prices, while allocative efficiency refers to profit maximization (cost minimization) at given prices (Latruffe, 2010). Technical, scale and allocative efficiency together form the economic efficiency (Zelenyuk, 2015). Hence, if a firm is not technically and/or scale efficient, then it cannot be economically efficient (Kumbhakar \& Knox Lovell, 2000).

Measuring efficiency presupposes the existence of a production boundary that reflects the efficient input-output subset. The formulation of such a theoretical framework allows us to consider technical efficiency as the distance from the point of the current inputoutput combination of the firm to the boundary (Farrell, 1957). Empirically speaking, the technical efficiency score of a firm represents the deviation of productive performance of this firm from the best practice. This deviation is usually assigned to either differential firm management 
capabilities (in other words to the different level of human capital; Mathijs \& Vranken, 2000) or to the external environment in which firms operate (Dimera et al., 2008) that is shaped by institutions (formal and informal rules, regulations and laws) (Gordon \& Davidova, 2004). Deeper insight into the technical inefficiency is provided by its decomposition into transient and persistent parts. The transient part of technical inefficiency relates to nonsystematic management problems, shocks associated with new production technologies, and changes in human capital (Njuki \& BravoUreta, 2015). According to Fillipini and Greene (2016), persistent technical inefficiency is related to the presence of structural problems in the organization of the production process or the presence of systematic shortfalls in managerial capabilities. Moreover, it can be an indicator of non-competitive market conditions. Badunenko and Kumbhakar (2016) state that persistent inefficiency could not exist in a competitive market, i.e., persistently inefficient firms would not survive in the business. The market organization is important also for scale efficiency. Firms in a competitive industry are assumed to be driven to produce at the lowest point of the long-run average cost curve (Gordon \& Davidova, 2004) representing the constant returns to scale and the scale efficiency of the firm, given its technical efficiency, presents how close the firm operates to the constant returns to scale or, in other words, it informs us if the firm has chosen the correct scale of inputs for the output it opts to produce (Dimara et al., 2008). Furthermore, according to Bokusheva and Čechura (2017), regulations of a market or deficiencies in the firm's external environment, as well as price uncertainty and risk aversion behaviour, can lead to allocative inefficiency, in other words, can hinder optimal allocation of resources given current market prices.

Efficiency is a prerequisite for profitability (Kumbhakar \& Lien, 2009). However, in the existing literature, very little attention has been paid to examine the relationship between efficiency and profitability of the enterprises, with exception of the banking system in developed and developing countries (e.g. Kumar, 2008). Especially in the industry, only a few studies investigate this relationship, namely Keramdiou et al. (2012) for the Greek meat processing industry, Gumbau and Maudos (2000) for the Spanish industry. The results of Keramidou et al. (2012) show that the firms with a higher technical efficiency are not usually the best performers in profitability. Gumbau and Maudos (2000) analyzed profitability, market structure, and efficiency for the Spanish industry, and found out that whereas technical efficiency does contribute positively to explaining differences in profitability, the market share, which would capture the effect of market power, affects it positively as well. Other prerequisites and determinants of the profitability of the food industry in the EU are then discussed, for example, by Hirsch et al. (2014), Hirsch and Schiefer (2016), and Gschwandtner and Hirsch (2018). Contrary to the relationship of technical efficiency and profitability, the analysis of technical efficiency and productivity received special attention in the research of the food processing industry over the last decade. For example, Kapelko (2019) investigated productivity dynamics based on technical change, technical inefficiency change, and scale inefficiency change of meat, dairy, fruit and vegetable, and bakery and farinaceous products manufacturing firms in European Union, Allendorf and Hirsch (2015) analysed technical efficiency of the European dairy and meat processing sectors, Soboh et al. (2014) investigated technical and scale efficiency of dairy processing firms in six European countries, and Čechura et al. (2014) analysed productivity dynamics taking into account technical efficiency, technological change, and heterogeneity (management effect) in the EU food processing industry and conducted comparative analysis among the different EU countries and different food industry sectors to identify the productive and less productive countries, sectors, and companies.

The efficiency of Czech food processing firms was recently analysed in several studies. Čechura and Žáková Kroupová (2021) investigated the technical efficiency of the dairy processing industry in $10 \mathrm{EU}$ Member States including the Czech Republic in the period 2006-2018. Their results reveal that the European dairy processing industry as a whole seems to be highly competitive and the companies, including the Czech ones, highly efficient. There are many factors that can support the efficiency and competitiveness of food processing firms. For example, investments, that induce technological innovation, positively contribute to the growth of technical efficiency, 
as was empirically confirmed by Rudinskaya and Kuzmenko (2019) investigating the dynamic linkages among investments, technical efficiency and productivity of the Czech meat, and dairy processing sectors in 2011-2015. Consequently, subsidies supporting investment and innovation activities have a positive effect on the competitiveness of subsidised companies as was pointed out by Rudinskaya and Naglova (2018) based on the empirical analysis of the Czech meat processing industry employing data from period 2007-2013. The impact of public support was investigated also by Vokoun et al. (2015) who evaluated the Czech and Slovak food processing industry. Their results point out that the stability of the sector is based on medium to large firms, which are very capable of using all kinds of public support and their advantage lies in increasing returns to scale which are beneficial to overall labour productivity. The determinants of entrepreneurial success of Czech food industry firms are dealt with by Blažková and Dvouletý $(2017,2019)$. The results of Blažková and Dvouletý report a positive influence of productivity and higher market concentration (2017) on profitability, and a negative influence of high indebtedness $(2017,2019)$. Important determinants of profitability are also firm size and firm age (2019). As far as we know, no authors are dealing with the relationship between technical and scale efficiency and profitability within the Czech food industry.

\section{Research Methodology \\ 2.1 Stochastic Frontier Model}

The analysis is based on the assumption that the Czech food processing companies follow the cost-minimizing behaviour. However, instead of a cost function, the analysis employs an input distance function (IDF), since no price information is necessary to its estimate (Kumbhakar et al., 2007). The input distance function first introduced by Shepard (1970) is defined on the input requirement set $L(y)$ as:

$$
D^{I}(x, y, t)=\max \left\{\rho: \frac{x}{\rho} \in L(y)\right\},
$$

where $x$ denotes the input vector, $y$ denotes the output vector (Caves et al., 1982), and $t$ is a time variable capturing technological change, in other words, the shift of frontier (Chambers, 1988).
The value of the input distance function measures the maximum amount by which the input vector can be deflated, given the output vector (Hailu \& Veeman, 2000). For any input-output combination $(x, y)$ belonging to the technology set, the distance function takes a value no smaller than unity (Irz \& Thirtle, 2005). According to Karagiannis et al. (2004), a value of unity simply indicates that the input-output combination $(x, y)$ belongs to the input isoquant which represents the minimum input quantities that are necessary to produce a given output vector $y$. Thus, by definition, the IDF provides a measure of technical efficiency since its reciprocal to the Farrell (1957) input-based technical efficiency: $T E^{I}=\frac{1}{D^{I}(x, y, t)}$. Moreover, the IDF exhibits the following properties: it is non-decreasing, continuous, concave, and homogeneous of degree one in inputs and an upper semicontinuous and quasi-concave function of output (Hailu \& Veeman, 2000). For the interpretation of the empirical estimates, the duality between the cost and input distance functions is another important property: $C(w, y, t)=\min _{x}\left\{w x: D^{I}(y, x, t) \geq 1\right\}$, where $w$ denotes a vector of input prices (Karagiannis et al., 2004). Irz and Thirtle (2005) present that based on this minimisation problem, the derivatives of the input distance function can be directly related to the cost function. Specifically, the derivative with respect to $j^{\text {th }}$ input gives:

$$
\frac{\partial D^{I}\left(x^{*}(w, y, t), y, t\right)}{\partial x_{j}}=\frac{w_{j}}{c(w, y, t)}=w_{j}^{S}(x, y, t),
$$

where $x^{*}($.$) denotes the vector of cost-$ minimising input quantities. Hence, the derivative of the input distance function with respect to a particular input is equal to the cost-deflated shadow price of that input $w_{j}^{s}$. According to Karagiannis et al. (2004), shadow price and market price coincide at the costminimizing input vector and consequently differences between marginal products of inputs derived from the IDF and observed input prices can be interpreted as the presence of allocative inefficiency (Bokusheva \& Čechura, 2017).

In terms of the log derivative of the distance function, we can rewrite the formula (2) to (3) and obtain the elasticity of the input-distance function with respect to a given input (Singbo \& Larue, 2016): 


$$
\frac{\partial \ln D^{I}(x, y, t)}{\partial \ln x_{j}}=S_{j, t},
$$

where $S_{j, t}$ is a cost-share of the $j^{\text {th }}$ input. Since the elasticity of the IDF with respect to $j^{\text {th }}$ input is equalto its cost share, it captures the relative importance of that input in the production process (Irz \& Thirtle, 2005).

The derivative with respect to the output vector allows to obtain returns to scale (RTS) measure (Karagiannis et al., 2004; Singbo \& Larue, 2016):

$$
R T S=-\left[\sum \frac{\partial \ln D^{I}(x, y, t)}{\partial \ln y_{m}}\right]^{-1}
$$

This measure reveals whether the technology exhibits increasing, constant or decreasing returns to scale. In other words, if a proportionate increase in all inputs results in a larger, equal or less than proportionate increase in the aggregate output, respectively (Baumol et al., 1982). Under a certain assumption (Morroni, 2006), the notions of increasing (decreasing) returns to scale can be considered equivalent to economies (diseconomies) of scale, that are present if costs increase by a smaller (larger) rate than output.

Finally, the log derivative of the IDF with respect to time provides a dual measure of technological change with a cost-saving interpretation (Karagiannis et al., 2004):

$$
T C H=-\frac{\partial \ln D^{I}(x, y, t)}{\partial t}=-\frac{\partial \ln C(w, y, t)}{\partial t} .
$$

A negative value for this measure indicates technological regress and a positive value technological progress (Irz \& Thirtle, 2005). Furthermore, a dual measure of a Hicksianstyle biased technological change can be obtained from the IDF based on the relative factor shares expressed in (3) as suggest Irz and Thirtle (2005):

$$
B T C H_{j}=-\frac{\partial^{2} \ln D^{I}(x, y, t)}{\partial \ln x_{j} \partial t}=-\frac{\partial s_{j, t}}{\partial t},
$$

where $S_{j, t}$ is cost-share of $j^{\text {th }}$ input. A positive (negative) value of $\mathrm{BTCHj}$ measure indicates that technological change is $j^{\text {th }}$ input-using (saving) (Irz \& Thirtle, 2005).
In order to keep the representation of production technology as flexible as possible, the translog functional form is chosen for the IDF specification in this study. The deterministic part of the model with $j$-inputs $(x)$, output $(y)$ and time $(t)$ therefore takes the following form:

$$
\begin{aligned}
& \ln D_{i t}^{I}=\alpha_{0}+\alpha_{m} \ln y_{i t}+\frac{1}{2} \alpha_{m m}\left(\ln y_{i t}\right)^{2}+ \\
& +\sum_{j=1}^{J} \gamma_{m j} \ln y_{i t} \ln x_{j, i t}+\sum_{j=1}^{J} \beta_{j} \ln x_{j, i t}+ \\
& +\frac{1}{2} \sum_{j=1}^{J} \sum_{k=1}^{K} \beta_{j k} \ln x_{j, i t} \ln x_{k, i t}+\delta_{t} t+ \\
& +\frac{1}{2} \delta_{t t} t^{2}+\delta_{m t} \ln y_{m, i t} t+\sum_{j=1}^{J} \delta_{j t} \ln x_{j, i t} t
\end{aligned}
$$

where subscripts $i$, with $i=1,2, \ldots, l$, and $t$, with $t=1, \ldots, T$, refer to a certain company and time (year), respectively. $\alpha, \beta, \gamma$, and $\delta$ are vectors of the parameters to be estimated. The function satisfied the symmetry restriction: $\beta_{j k}=\beta_{k j}$ (Tsionas et al., 2015) and homogeneity of degree one in inputs if: $\sum_{j=1}^{J} \beta_{j}=1 ; \sum_{j=1}^{J} \beta_{j k}=0 ; \sum_{j=1}^{J} \gamma_{m j}=0 ; \sum_{j=1}^{J} \delta_{j t}=0$ (Karagiannis et al., 2004).

The homogeneity restriction is imposed by normalising all the inputs by one input (Singbo \& Larue, 2016) ( $x_{1}$ in this case):

$$
\begin{aligned}
& \ln D_{i t}^{I}-\ln x_{1 i t}=\alpha_{0}+\alpha_{m} \ln y_{i t}+\frac{1}{2} \alpha_{m m}\left(\ln y_{i t}\right)^{2}+ \\
& +\sum_{j=2}^{J} \gamma_{m j} \ln y_{i t} \ln \tilde{x}_{j, i t}+\sum_{j=2}^{J} \beta_{j} \ln \tilde{x}_{j, i t}+ \\
& +\frac{1}{2} \sum_{j=2}^{J} \sum_{k=2}^{K} \beta_{j k} \ln \tilde{x}_{j, i t} \ln \tilde{x}_{k, i t}+\delta_{t} t+\frac{1}{2} \delta_{t t} t^{2}+ \\
& +\delta_{m t} \ln y_{m, i t} t+\sum_{j=2}^{J} \delta_{j t} \ln \tilde{x}_{j, i t} t
\end{aligned}
$$

where $\ln \tilde{x}_{j, i t}=\ln x_{j, i t}-\ln x_{1, i t}$.

Given that $\ln D_{i t}^{I}=u_{i t}+\eta_{i}$ (Coelli \& Perelman, 2000; Baležentis \& Sun, 2020), where $u_{i t}$ denotes transient technical inefficiency and $\eta_{i}$ denotes persistent technical inefficiency and introducing latent heterogeneity $\left(\mu_{i}\right)$ and statistical error term $\left(v_{i t}\right)$, the model can be rewritten to the form of a Generalized True Random Effect model (GTRE, Kumbhakar \& Tsionas, 2012):

$$
\begin{aligned}
& -\ln x_{1, i t}=\alpha_{0}+\alpha_{m} \ln y_{i t}+\frac{1}{2} \alpha_{m m}\left(\ln y_{i t}\right)^{2}+ \\
& +\sum_{j=2}^{J} \beta_{j} \ln \tilde{x}_{j, i t}+\frac{1}{2} \sum_{j=2}^{J} \sum_{k=2}^{K} \beta_{j k} \ln \tilde{x}_{j, i t} \ln \tilde{x}_{k, i t}+ \\
& +\sum_{j=2}^{J} \gamma_{m j} \ln y_{i t} \ln \tilde{x}_{j, i t}+\delta_{t} t+\frac{1}{2} \delta_{t t} t^{2}+ \\
& +\delta_{m t} \ln y_{m, i t}+\sum_{j=2}^{J} \delta_{j t} \ln \tilde{x}_{j, i t} t-\eta_{i}-u_{i t}+ \\
& +\mu_{i}+v_{i t},
\end{aligned}
$$

where $v_{i t} \sim N\left(0, \sigma_{v}^{2}\right) ; u_{i t} \sim N^{+}\left(0, \sigma_{u}^{2}\right) ; \eta_{i} \sim N^{+}\left(0, \sigma_{\eta}^{2}\right)$, $\mu_{i} \sim N\left(0, \sigma_{\mu}^{2}\right)$. 


\title{
DRIVERS OF ECONOMIC PERFORMANCE: WHAT CAN WE OBSERVE IN THE CZECH FOOD INDUSTRY?
}

\author{
Gabriela Trnková1, Zdeňka Žáková Kroupová
}

\footnotetext{
1 University of Hradec Králové, Faculty of Informatics and Management, Department of Economics, Czech Republic, ORCID: 0000-0001-5181-5689, gabriela.trnkova@uhk.cz;

2 Czech University of Life Sciences Prague, Faculty of Economics and Management, Department of Economics, Czech Republic, ORCID: 0000-0001-5834-3338, kroupovaz@pef.czu.cz.
}

\begin{abstract}
This paper is focused on the investigation of the competitiveness drivers, namely technical and scale efficiency and technological change, and their relation to the profitability of the Czech food processing companies in the period 2016-2019. This investigation is based on the stochastic frontier modelling of an input distance function in the specification of the four-errorcomponent model. The model is estimated with a multi-step procedure employing the generalized method of moments estimator addressing the potential endogeneity of netputs, and panel data gained from the Bisnode Albertina database. The results revealed (evaluated on the sample mean) that investigated food processing sectors were scale efficient in the analysed period, however, their production technologies exhibited prevailing technological regress. Moreover, the room for almost $17 \%$ cost reduction by the technical efficiency improvements was found out in all investigated sectors. Although inter-sectoral differences exist in the scale efficiency, technological change and technical efficiency dynamics, to increase the productivity and competitiveness of food processing companies, it is generally appropriate to focus on technical efficiency and technological change improvements. Both these competitiveness drivers connected with the cost reduction and minimizing of wastage of inputs are achievable through innovations. In general, the basic source of their financing is profit, the achievement of which is supported by cost minimization. However, it was found that sub-sectors, which are linked to sensitive sectors of agricultural production that means sectors with the lowest national self-sufficiency, the highest level of imports and thus strong cost reduction pressure - have problem to translate the ability to produce efficiently into profitability. Although these food sectors, which have been also facing strong competition for a long time, which leads to significant pressure to reduce costs, achieved the highest technical efficiency, their profitability was lowest from the investigated sectors.
\end{abstract}

Keywords: Stochastic frontier analysis, technical efficiency, profitability, food processing industry, the Czech Republic.

JEL Classification: D24, L66.

APA Style Citation: Trnková, G., \& Žáková Kroupová, Z. (2021). Drivers of Economic Performance: What Can We Observe in the Czech Food Industry? E\&M Economics and Management, 24(3), 110-127. https://doi.org/10.15240/tul/001/2021-03-007

\section{Introduction}

The production of food products is one of the strategic branches of the manufacturing industry, as it supplies food to the market and thus ensures the diet of the population. In 2018, based on data from the Ministry of Industry and Trade (MPO, 2019), the food industry accounted for $5.4 \%$ of the total value added of the manufacturing industry. Furthermore, $7.6 \%$ of employees in the total number of manufacturing industry workers demonstrate social importance, however, with a significant 
wage disparity compared to other sectors of the manufacturing industry. The business structure of the Czech food industry is represented mainly by small and medium-sized enterprises and so the importance of this sector is also irreplaceable from rural development point of vies. However, in a strong competitive environment, more and more production concentration and at the same time specialization are manifested. Mezera et al. (2019) state, that foreign capital enters just sub-sectors with sufficient quality raw materials and companies with concentration production and thus with necessary capacities, and they mention the dairy industry as an example.

With the accession of the Czech Republic to the EU, the Czech food industry is facing much greater competitive pressure than in the past, which requires producers to operate more efficiently and innovatively. Blažková and Dvouletý (2019) mention some of the challenges facing the Czech food industry, especially lack of technological capabilities and managerial skills, high corporate indebtedness, and disadvantageous market position against retail. The overcrowded retail network in the Czech Republic (after the entry of large multinational chains into the Czech retail market) distorts the natural competitive environment and forces traders to assert themselves on price, which leads primarily to a reduction in production costs for their suppliers (MPO, 2019). All these problems have affected the efficiency and profitability and thus the competitiveness of not only the food industry but the whole agri-food sector as well.

Therefore, this study investigates the basic prerequisites of competitiveness - technical and scale efficiency and technological change and examines if these drivers are translated into a better competitive position and thus into higher profitability. The partial goals of this paper are as follows:

1. measure and compare the returns to scale, technological change, and technical efficiency for the Czech food industry and its particular sub-sectors;

2. examine the relationship between these drivers and profitability.

In the following section, we briefly introduce the theoretical background of our research. Further, the model and estimation strategy are described, and then dataset and variables are introduced. The next part is dedicated to the interpretation of the obtained results. Finally, some conclusions summarizing the main findings and implications are drawn.

\section{Theoretical Background}

Economic performance is usually viewed in terms of profitability, productivity, and efficiency. Efficiency is a multi-faceted phenomenon. Generally speaking, it indicates whether a firm is able to use the existing technology in the best way (Latruffe, 2010). In output orientation, it refers to the firm's ability to produce the optimal quantities of output in a certain technological regime (environment) and at given input quantities. In input orientation, it represents the firm's ability to produce a given level of output in a certain technological regime using the minimum quantity of inputs (Dimara et al., 2008). Economic theory distinguishes technical efficiency that refers to the firm's ability to minimize input use in the production of a given output vector, or the ability to obtain maximum output from a given input vector (Kumbhakar \& Knox Lovell, 2000); scale efficiency that gives insights into whether the firm operates at the most productive scale size where the average productivity reaches a maximum level (Kounetas \& Tsekouras, 2007); and allocative efficiency that is linked to the ability of a firm to produce at a given level of output using inputs in their optimal proportions given their respective prices, or to produce an optimal combination of outputs given their respective prices (Farrell, 1957). Obviously, technical and scale efficiency refers to a physical notion, independent of input and output prices, while allocative efficiency refers to profit maximization (cost minimization) at given prices (Latruffe, 2010). Technical, scale and allocative efficiency together form the economic efficiency (Zelenyuk, 2015). Hence, if a firm is not technically and/or scale efficient, then it cannot be economically efficient (Kumbhakar \& Knox Lovell, 2000).

Measuring efficiency presupposes the existence of a production boundary that reflects the efficient input-output subset. The formulation of such a theoretical framework allows us to consider technical efficiency as the distance from the point of the current inputoutput combination of the firm to the boundary (Farrell, 1957). Empirically speaking, the technical efficiency score of a firm represents the deviation of productive performance of this firm from the best practice. This deviation is usually assigned to either differential firm management 
capabilities (in other words to the different level of human capital; Mathijs \& Vranken, 2000) or to the external environment in which firms operate (Dimera et al., 2008) that is shaped by institutions (formal and informal rules, regulations and laws) (Gordon \& Davidova, 2004). Deeper insight into the technical inefficiency is provided by its decomposition into transient and persistent parts. The transient part of technical inefficiency relates to nonsystematic management problems, shocks associated with new production technologies, and changes in human capital (Njuki \& BravoUreta, 2015). According to Fillipini and Greene (2016), persistent technical inefficiency is related to the presence of structural problems in the organization of the production process or the presence of systematic shortfalls in managerial capabilities. Moreover, it can be an indicator of non-competitive market conditions. Badunenko and Kumbhakar (2016) state that persistent inefficiency could not exist in a competitive market, i.e., persistently inefficient firms would not survive in the business. The market organization is important also for scale efficiency. Firms in a competitive industry are assumed to be driven to produce at the lowest point of the long-run average cost curve (Gordon \& Davidova, 2004) representing the constant returns to scale and the scale efficiency of the firm, given its technical efficiency, presents how close the firm operates to the constant returns to scale or, in other words, it informs us if the firm has chosen the correct scale of inputs for the output it opts to produce (Dimara et al., 2008). Furthermore, according to Bokusheva and Čechura (2017), regulations of a market or deficiencies in the firm's external environment, as well as price uncertainty and risk aversion behaviour, can lead to allocative inefficiency, in other words, can hinder optimal allocation of resources given current market prices.

Efficiency is a prerequisite for profitability (Kumbhakar \& Lien, 2009). However, in the existing literature, very little attention has been paid to examine the relationship between efficiency and profitability of the enterprises, with exception of the banking system in developed and developing countries (e.g. Kumar, 2008). Especially in the industry, only a few studies investigate this relationship, namely Keramdiou et al. (2012) for the Greek meat processing industry, Gumbau and Maudos (2000) for the Spanish industry. The results of Keramidou et al. (2012) show that the firms with a higher technical efficiency are not usually the best performers in profitability. Gumbau and Maudos (2000) analyzed profitability, market structure, and efficiency for the Spanish industry, and found out that whereas technical efficiency does contribute positively to explaining differences in profitability, the market share, which would capture the effect of market power, affects it positively as well. Other prerequisites and determinants of the profitability of the food industry in the EU are then discussed, for example, by Hirsch et al. (2014), Hirsch and Schiefer (2016), and Gschwandtner and Hirsch (2018). Contrary to the relationship of technical efficiency and profitability, the analysis of technical efficiency and productivity received special attention in the research of the food processing industry over the last decade. For example, Kapelko (2019) investigated productivity dynamics based on technical change, technical inefficiency change, and scale inefficiency change of meat, dairy, fruit and vegetable, and bakery and farinaceous products manufacturing firms in European Union, Allendorf and Hirsch (2015) analysed technical efficiency of the European dairy and meat processing sectors, Soboh et al. (2014) investigated technical and scale efficiency of dairy processing firms in six European countries, and Čechura et al. (2014) analysed productivity dynamics taking into account technical efficiency, technological change, and heterogeneity (management effect) in the EU food processing industry and conducted comparative analysis among the different EU countries and different food industry sectors to identify the productive and less productive countries, sectors, and companies.

The efficiency of Czech food processing firms was recently analysed in several studies. Čechura and Žáková Kroupová (2021) investigated the technical efficiency of the dairy processing industry in $10 \mathrm{EU}$ Member States including the Czech Republic in the period 2006-2018. Their results reveal that the European dairy processing industry as a whole seems to be highly competitive and the companies, including the Czech ones, highly efficient. There are many factors that can support the efficiency and competitiveness of food processing firms. For example, investments, that induce technological innovation, positively contribute to the growth of technical efficiency, 
as was empirically confirmed by Rudinskaya and Kuzmenko (2019) investigating the dynamic linkages among investments, technical efficiency and productivity of the Czech meat, and dairy processing sectors in 2011-2015. Consequently, subsidies supporting investment and innovation activities have a positive effect on the competitiveness of subsidised companies as was pointed out by Rudinskaya and Naglova (2018) based on the empirical analysis of the Czech meat processing industry employing data from period 2007-2013. The impact of public support was investigated also by Vokoun et al. (2015) who evaluated the Czech and Slovak food processing industry. Their results point out that the stability of the sector is based on medium to large firms, which are very capable of using all kinds of public support and their advantage lies in increasing returns to scale which are beneficial to overall labour productivity. The determinants of entrepreneurial success of Czech food industry firms are dealt with by Blažková and Dvouletý $(2017,2019)$. The results of Blažková and Dvouletý report a positive influence of productivity and higher market concentration (2017) on profitability, and a negative influence of high indebtedness $(2017,2019)$. Important determinants of profitability are also firm size and firm age (2019). As far as we know, no authors are dealing with the relationship between technical and scale efficiency and profitability within the Czech food industry.

\section{Research Methodology \\ 2.1 Stochastic Frontier Model}

The analysis is based on the assumption that the Czech food processing companies follow the cost-minimizing behaviour. However, instead of a cost function, the analysis employs an input distance function (IDF), since no price information is necessary to its estimate (Kumbhakar et al., 2007). The input distance function first introduced by Shepard (1970) is defined on the input requirement set $L(y)$ as:

$$
D^{I}(x, y, t)=\max \left\{\rho: \frac{x}{\rho} \in L(y)\right\},
$$

where $x$ denotes the input vector, $y$ denotes the output vector (Caves et al., 1982), and $t$ is a time variable capturing technological change, in other words, the shift of frontier (Chambers, 1988).
The value of the input distance function measures the maximum amount by which the input vector can be deflated, given the output vector (Hailu \& Veeman, 2000). For any input-output combination $(x, y)$ belonging to the technology set, the distance function takes a value no smaller than unity (Irz \& Thirtle, 2005). According to Karagiannis et al. (2004), a value of unity simply indicates that the input-output combination $(x, y)$ belongs to the input isoquant which represents the minimum input quantities that are necessary to produce a given output vector $y$. Thus, by definition, the IDF provides a measure of technical efficiency since its reciprocal to the Farrell (1957) input-based technical efficiency: $T E^{I}=\frac{1}{D^{I}(x, y, t)}$. Moreover, the IDF exhibits the following properties: it is non-decreasing, continuous, concave, and homogeneous of degree one in inputs and an upper semicontinuous and quasi-concave function of output (Hailu \& Veeman, 2000). For the interpretation of the empirical estimates, the duality between the cost and input distance functions is another important property: $C(w, y, t)=\min _{x}\left\{w x: D^{I}(y, x, t) \geq 1\right\}$, where $w$ denotes a vector of input prices (Karagiannis et al., 2004). Irz and Thirtle (2005) present that based on this minimisation problem, the derivatives of the input distance function can be directly related to the cost function. Specifically, the derivative with respect to $j^{\text {th }}$ input gives:

$$
\frac{\partial D^{I}\left(x^{*}(w, y, t), y, t\right)}{\partial x_{j}}=\frac{w_{j}}{c(w, y, t)}=w_{j}^{S}(x, y, t),
$$

where $x^{*}($.$) denotes the vector of cost-$ minimising input quantities. Hence, the derivative of the input distance function with respect to a particular input is equal to the cost-deflated shadow price of that input $w_{j}^{s}$. According to Karagiannis et al. (2004), shadow price and market price coincide at the costminimizing input vector and consequently differences between marginal products of inputs derived from the IDF and observed input prices can be interpreted as the presence of allocative inefficiency (Bokusheva \& Čechura, 2017).

In terms of the log derivative of the distance function, we can rewrite the formula (2) to (3) and obtain the elasticity of the input-distance function with respect to a given input (Singbo \& Larue, 2016): 


$$
\frac{\partial \ln D^{I}(x, y, t)}{\partial \ln x_{j}}=S_{j, t},
$$

where $S_{j, t}$ is a cost-share of the $j^{\text {th }}$ input. Since the elasticity of the IDF with respect to $j^{\text {th }}$ input is equalto its cost share, it captures the relative importance of that input in the production process (Irz \& Thirtle, 2005).

The derivative with respect to the output vector allows to obtain returns to scale (RTS) measure (Karagiannis et al., 2004; Singbo \& Larue, 2016):

$$
R T S=-\left[\sum \frac{\partial \ln D^{I}(x, y, t)}{\partial \ln y_{m}}\right]^{-1}
$$

This measure reveals whether the technology exhibits increasing, constant or decreasing returns to scale. In other words, if a proportionate increase in all inputs results in a larger, equal or less than proportionate increase in the aggregate output, respectively (Baumol et al., 1982). Under a certain assumption (Morroni, 2006), the notions of increasing (decreasing) returns to scale can be considered equivalent to economies (diseconomies) of scale, that are present if costs increase by a smaller (larger) rate than output.

Finally, the log derivative of the IDF with respect to time provides a dual measure of technological change with a cost-saving interpretation (Karagiannis et al., 2004):

$$
T C H=-\frac{\partial \ln D^{I}(x, y, t)}{\partial t}=-\frac{\partial \ln C(w, y, t)}{\partial t} .
$$

A negative value for this measure indicates technological regress and a positive value technological progress (Irz \& Thirtle, 2005). Furthermore, a dual measure of a Hicksianstyle biased technological change can be obtained from the IDF based on the relative factor shares expressed in (3) as suggest Irz and Thirtle (2005):

$$
B T C H_{j}=-\frac{\partial^{2} \ln D^{I}(x, y, t)}{\partial \ln x_{j} \partial t}=-\frac{\partial s_{j, t}}{\partial t},
$$

where $S_{j, t}$ is cost-share of $j^{\text {th }}$ input. A positive (negative) value of $\mathrm{BTCHj}$ measure indicates that technological change is $j^{\text {th }}$ input-using (saving) (Irz \& Thirtle, 2005).
In order to keep the representation of production technology as flexible as possible, the translog functional form is chosen for the IDF specification in this study. The deterministic part of the model with $j$-inputs $(x)$, output $(y)$ and time $(t)$ therefore takes the following form:

$$
\begin{aligned}
& \ln D_{i t}^{I}=\alpha_{0}+\alpha_{m} \ln y_{i t}+\frac{1}{2} \alpha_{m m}\left(\ln y_{i t}\right)^{2}+ \\
& +\sum_{j=1}^{J} \gamma_{m j} \ln y_{i t} \ln x_{j, i t}+\sum_{j=1}^{J} \beta_{j} \ln x_{j, i t}+ \\
& +\frac{1}{2} \sum_{j=1}^{J} \sum_{k=1}^{K} \beta_{j k} \ln x_{j, i t} \ln x_{k, i t}+\delta_{t} t+ \\
& +\frac{1}{2} \delta_{t t} t^{2}+\delta_{m t} \ln y_{m, i t} t+\sum_{j=1}^{J} \delta_{j t} \ln x_{j, i t} t
\end{aligned}
$$

where subscripts $i$, with $i=1,2, \ldots, l$, and $t$, with $t=1, \ldots, T$, refer to a certain company and time (year), respectively. $\alpha, \beta, \gamma$, and $\delta$ are vectors of the parameters to be estimated. The function satisfied the symmetry restriction: $\beta_{j k}=\beta_{k j}$ (Tsionas et al., 2015) and homogeneity of degree one in inputs if: $\sum_{j=1}^{J} \beta_{j}=1 ; \sum_{j=1}^{J} \beta_{j k}=0 ; \sum_{j=1}^{J} \gamma_{m j}=0 ; \sum_{j=1}^{J} \delta_{j t}=0$ (Karagiannis et al., 2004).

The homogeneity restriction is imposed by normalising all the inputs by one input (Singbo \& Larue, 2016) ( $x_{1}$ in this case):

$$
\begin{aligned}
& \ln D_{i t}^{I}-\ln x_{1 i t}=\alpha_{0}+\alpha_{m} \ln y_{i t}+\frac{1}{2} \alpha_{m m}\left(\ln y_{i t}\right)^{2}+ \\
& +\sum_{j=2}^{J} \gamma_{m j} \ln y_{i t} \ln \tilde{x}_{j, i t}+\sum_{j=2}^{J} \beta_{j} \ln \tilde{x}_{j, i t}+ \\
& +\frac{1}{2} \sum_{j=2}^{J} \sum_{k=2}^{K} \beta_{j k} \ln \tilde{x}_{j, i t} \ln \tilde{x}_{k, i t}+\delta_{t} t+\frac{1}{2} \delta_{t t} t^{2}+ \\
& +\delta_{m t} \ln y_{m, i t} t+\sum_{j=2}^{J} \delta_{j t} \ln \tilde{x}_{j, i t} t
\end{aligned}
$$

where $\ln \tilde{x}_{j, i t}=\ln x_{j, i t}-\ln x_{1, i t}$.

Given that $\ln D_{i t}^{I}=u_{i t}+\eta_{i}$ (Coelli \& Perelman, 2000; Baležentis \& Sun, 2020), where $u_{i t}$ denotes transient technical inefficiency and $\eta_{i}$ denotes persistent technical inefficiency and introducing latent heterogeneity $\left(\mu_{i}\right)$ and statistical error term $\left(v_{i t}\right)$, the model can be rewritten to the form of a Generalized True Random Effect model (GTRE, Kumbhakar \& Tsionas, 2012):

$$
\begin{aligned}
& -\ln x_{1, i t}=\alpha_{0}+\alpha_{m} \ln y_{i t}+\frac{1}{2} \alpha_{m m}\left(\ln y_{i t}\right)^{2}+ \\
& +\sum_{j=2}^{J} \beta_{j} \ln \tilde{x}_{j, i t}+\frac{1}{2} \sum_{j=2}^{J} \sum_{k=2}^{K} \beta_{j k} \ln \tilde{x}_{j, i t} \ln \tilde{x}_{k, i t}+ \\
& +\sum_{j=2}^{J} \gamma_{m j} \ln y_{i t} \ln \tilde{x}_{j, i t}+\delta_{t} t+\frac{1}{2} \delta_{t t} t^{2}+ \\
& +\delta_{m t} \ln y_{m, i t}+\sum_{j=2}^{J} \delta_{j t} \ln \tilde{x}_{j, i t} t-\eta_{i}-u_{i t}+ \\
& +\mu_{i}+v_{i t},
\end{aligned}
$$

where $v_{i t} \sim N\left(0, \sigma_{v}^{2}\right) ; u_{i t} \sim N^{+}\left(0, \sigma_{u}^{2}\right) ; \eta_{i} \sim N^{+}\left(0, \sigma_{\eta}^{2}\right)$, $\mu_{i} \sim N\left(0, \sigma_{\mu}^{2}\right)$. 


\subsection{Estimation Strategy}

The GTRE model specified in formula (9) can be estimated by a multistep procedure introduced by Kumbahakar et al. (2014). However, this procedure does not address an endogeneity problem with input quantities in a single equation estimation of the IDF under the assumption of cost-minimizing behaviour (Karagiannis et al., 2004). In general, under the assumption, that a producer seeks to minimize or maximize some objective function, the levels of inputs and outputs are determined by a producer. Thus, they are neither randomly decided nor exogenously given (Lien et al., 2018). In the case of the cost-minimizing behaviour and the IDF function, the quantities of inputs are supposed to be chosen with the cost-minimizing objective in mind which makes inputs variable economically endogenous. As Lien et al. (2018) state the economic endogeneity usually leads to econometric endogeneity, which refers to the correlation of an explanatory variable and the composite error term. Resulting endogeneity bias can cause inconsistent estimates which potentially leads to wrong inferences and misleading conclusions (Ullah et al., 2018). To control endogeneity, Bokusheva and Čechura (2017) extended the Kumbhakar et al.'s (2014) multistep procedure. According to their approach, this study employs the two-step system generalized method of moments estimator (GMM) in step 1. The GMM controls for endogeneity by building a system of equations and uses two types of instruments: level instruments for the transformed (differenced) equation and lagged differences for the original equation (Roodman, 2009). The validity of instruments can be tested by the Hansen J-test, which evaluates the joint validity of the instruments, and the Arellano-Bond test for the autocorrelation which evaluates lags as valid instruments (Roodman, 2009). In step 2, residuals are used from the system GMM level equation to estimate a random effects panel model employing the generalized least squares (GLS) estimator with the aim to obtain theoretical values of $\alpha_{i}=\mu_{i}$ - $\left(\eta_{i}-E\left(\eta_{i}\right)\right)$ and $\varepsilon_{i t}=v_{i t}-\left(u_{i t}-E\left(u_{i t}\right)\right)$. In line with Kumbhakar et al. (2014), in step 3, the transient technical inefficiency is estimated from the theoretical value of $\varepsilon_{i t}$ using the standard stochastic frontier technique with assumptions: $v_{i t} \sim N\left(0, \sigma_{v}^{2}\right), u_{i t} \sim N^{+}\left(0, \sigma_{u}^{2}\right)$. Finally, in step 4 , the persistent technical inefficiency is estimated using the theoretical value of $\alpha_{i}$ and the stochastic frontier model with the following assumptions: $\mu_{i} \sim N\left(0, \sigma_{\mu}^{2}\right)$, $\eta_{i} \sim N^{+}\left(0, \sigma_{\eta}^{2}\right)$. Moreover, as a product of transient and persistent technical efficiency, the overall technical efficiency (OTE) can be quantified (Kumbhakar et al., 2014): OTE ${ }_{i t}=$ $\exp \left(-\hat{u}_{i 0}\right) * \exp \left(-\hat{u}_{i t}\right)$. In this study, all these estimates are done in the SW STATA 14.0.

\subsection{Data}

The study employs micro-level data of the Czech food processing industry gained from the database Bisnode Albertina. This database, containing the income statements and balance sheets of companies, was used in the Czech food processors performance analysis for example by Rudinskaya and Kuzmenko (2019), Blažková and Dvouletý (2019), and Čechura and Hockmann (2010).

In particular, this study focuses on the following NACE (Nomenclature of Economic Activities):

C 10.1 Processing and preserving of meat and production of meat products;

C 10.3 Processing and preserving of fruit and vegetables;

C 10.5 Manufacture of dairy products;

C 10.6 Manufacture of grain mill products, starches, and starch products;

C 10.7 Manufacture of bakery and farinaceous products;

C 10.9 Manufacture of prepared animal feeds.

Together these NACE sub-sectors represent $74 \%$ of total turnovers of the food processing industry in the Czech Republic (see Mezera et al., 2019). The original dataset was processed to include food processing companies with the complete financial statements and at least three consecutive years of observations in the period 2016-2019. This procedure decreases the problem associated with the entry and exit of companies from the database and allows the use of the GMM estimator with a sufficient number of lagged instruments (Čechura \& Žáková Kroupová, 2021). The final dataset consists of 1,667 observations of 468 companies. Tab. 1 presents the structure of the dataset based on NACE sub-sectors and the share of this sample on the total turnover and on the total personnel costs of NACE sub-sectors.

Specifically, for the IDF estimation, the analysis uses the following data: output $(y)$, represented by revenues from the sale of own products and services, revenues from sold 


\section{Tab. 1: Structure of the dataset}

\begin{tabular}{c|c|c|c|c} 
NACE & $\begin{array}{c}\text { Number } \\
\text { of companies }\end{array}$ & $\begin{array}{c}\text { Number } \\
\text { of observations }\end{array}$ & $\begin{array}{c}\text { Share on total } \\
\text { NACE turnover }\end{array}$ & $\begin{array}{c}\text { Share on total NACE } \\
\text { personnel costs }\end{array}$ \\
\hline 10.1 & 108 & 378 & $55 \%$ & $54 \%$ \\
\hline 10.3 & 31 & 112 & $91 \%$ & $88 \%$ \\
\hline 10.5 & 48 & 176 & $85 \%$ & $83 \%$ \\
\hline 10.6 & 37 & 128 & $56 \%$ & $56 \%$ \\
\hline 10.7 & 183 & 646 & $63 \%$ & $60 \%$ \\
\hline 10.9 & 61 & 227 & $90 \%$ & $89 \%$ \\
\hline
\end{tabular}

Source: own

goods, change in inventory of own products, and capitalisation deflated by the NACE sub-sector index of food processing prices $(2015=100)$; labour $(x L)$, represented by the personnel costs deflated by the index of gross wages and salaries in the manufacturing industry $(2015=100)$; capital $(x C)$, represented by the book value of fixed assets deflated by the index of producer prices in the industry $(2015=100)$; and material $(x M)$ - the total cost of materials and energy deflated by the index of producer prices in the industry $(2015=100)$. All these price indexes are gained from the Czech Statistical Office.

Three indicators were used to measure the profitability of sub-sectors: return on sales (ROS), return on assets (ROA), and return on costs (ROC). ROS calculates how efficiently a company is at generating net profits from its sales, ROA measures the management ability to generate profits from the firm's assets regardless of the way of funding and $\mathrm{ROC}$ expresses the ratio between the net profit of a firm and its costs, in our case, only operating profit and total operating costs were included.

\section{Research Results}

The IDF estimate is presented in Annex. The theoretical consistency of the estimated stochastic input-distance function requires the estimated parameters to support the assumptions of monotonicity and quasiconcavity. Tab. A1 in Annex presents that all first-order coefficients have the expected signs ( $\alpha_{m}<0, \beta_{j}>0$ for all inputs) implying that the IDF is non-increasing in output and non-decreasing in inputs at the sample mean since all variables in logarithm are normalized by their sample mean. These results indicate that monotonicity conditions are fulfilled at the sample mean (Singbo \& Larue, 2016). To be the IDF concave in inputs and quasiconcave in outputs, the Hessian matrix of second-order IDF's parameter derivative must be negative-definite with respect to outputs and positive-definite with respect to inputs, at the point of approximation (Karagiannis et al., 2004). This is fulfilled at the sample mean, if $\beta_{i j}+\beta_{j}^{2}-\beta_{j}<0 \forall j$ (Čechura \& Hockmann, 2017). Since all these conditions are met, the majority of parameters are statistically significant even at $5 \%$ significance level and the $\mathrm{AR}(2)$ test, and the Hansen's J-test statistics confirm the validity of GMM estimates, the estimated input-distance function seems to well approximate the production behaviour of food processors. It is worth mentioned, that the IDF was also estimated with dummy variables to capture inter-sectoral differences in the IDF's first-order parameters. Contrary to Čechura and Malá (2014), but in line with Čechura and Žáková Kroupová (2021), this heterogeneity was not statistically proved in the evaluated sample. Moreover, the IDF estimated with these dummy variables lost theoretical properties.

Estimated input shares, presented in Tab. 2, reveal that the Czech food processors use highly material-intensive production technology. The share of material in total input is $73 \%$ evaluated on the sample mean. On the other hand, the share of capital is the lowest from the evaluated inputs, $6 \%$, evaluated on the sample mean. As supposed, the Czech food processing industry can be characterized with higher labour than capital intensity, however, 
Tab. 2: Input-shares

\begin{tabular}{l|c|c|c} 
& Estimated sample mean & $\begin{array}{c}\text { NACE sub-sector } \\
\text { with the lowest mean }\end{array}$ & $\begin{array}{c}\text { NACE sub-sector } \\
\text { with the highest mean }\end{array}$ \\
\hline Labour-share & $21.1 \%$ & 10.9 & 10.7 \\
\hline Material-share & $72.9 \%$ & 10.7 & 10.5 \\
\hline Capital-share & $6.0 \%$ & 10.7 & 10.9 \\
\hline
\end{tabular}

Source: own

Tab. 3: Returns to scale, technological change, and technical efficiency

\begin{tabular}{l|c|c|c|c|c|c|c} 
& Min. & $\mathbf{1}^{\text {st }} \mathbf{Q}$ & Median & Mean & $\mathbf{3}^{\text {th }} \mathbf{Q}$ & Max. & Std. dev. \\
\hline Returns to scale & 0.800 & 0.960 & 1.000 & 1.005 & 1.049 & 1.261 & 0.063 \\
\hline Technological change & -0.081 & -0.029 & -0.009 & -0.009 & 0.011 & 0.089 & 0.028 \\
\hline Transient t. efficiency & 0.486 & 0.931 & 0.939 & 0.935 & 0.946 & 0.992 & 0.028 \\
\hline Persistent t. efficiency & 0.514 & 0.878 & 0.902 & 0.892 & 0.917 & 0.973 & 0.048 \\
\hline Overall t. efficiency & 0.391 & 0.819 & 0.845 & 0.834 & 0.863 & 0.952 & 0.055 \\
\hline
\end{tabular}

Source: own

the biased technological change reveals (in line with the results of Rudinskaya \& Kuzmenko, 2019), that the technology is labour-saving. It is worth mentioned, that the estimated inputshares are consistent with information in the data set not only at the total sample mean but also evaluated on the NACE sub-sectors means. The estimates of NACE sub-sectors means of input-shares reveal that producers in the NACE 10.7 (Manufacture of bakery and farinaceous products) employ the most labour-intensive and the least material- and capital-intensive technology from investigated sub-sectors. On the other hand, the technology of the animal feeds producers (NACE 10.9) is the least labour-intensive but the most capitalintensive from the evaluated NACE sub-sectors. This confirms that the IDF estimate follows the nature of the production process.

The estimated elasticity of output $(-0.99)$ reveals that the production process occurs under the optimal scale, evaluated on the sample mean. In other words, the average company in the sample is scale efficient as revealed also Čechura and Hockmann (2010) evaluating the Czech food processing industry in the period 1992-2007. Tab. 3 presents the descriptive statistics of the dual measure - returns to scale (RTS) which confirm the high scale efficiency of food processors, evaluated on the sample mean. However, the inter- and intra-sectoral differences can be observed, see Fig. 1.

The highest mean value (1.05) is revealed in NACE 10.5 (Manufacture of dairy products), indicating that the average dairy processing company can be characterized by increasing returns to scale. According to Chirinko and Fazzari (1994), this can indicate the existence of the market power of dairy processing firms. On the other hand, the lowest mean value $(0.97)$ is observable in NACE 10.7. (Manufacture of bakery and farinaceous products), revealing decreasing returns to scale in this sub-sector of food processing. Moreover, the constant returns to scale, representing optimal scale of operation, are confirmed by t-test $(\mathrm{t}=1.569$, $\operatorname{Pr}(|T|>|t|)=0.119$ ) in NACE 10.6 (Manufacture of grain mill products, starches and starch products), evaluated on the sub-sector mean.

In all investigated sub-sectors, the few cases of increasing (RTS $>1$ ), as well as decreasing (RTS $<1)$, returns to scale can be revealed indicating sub-optimal scale of operations. Moreover, in analysed time, it can be observed that producers have moved away from the 


\section{Fig. 1: Distribution and development of returns to scale and technological change}

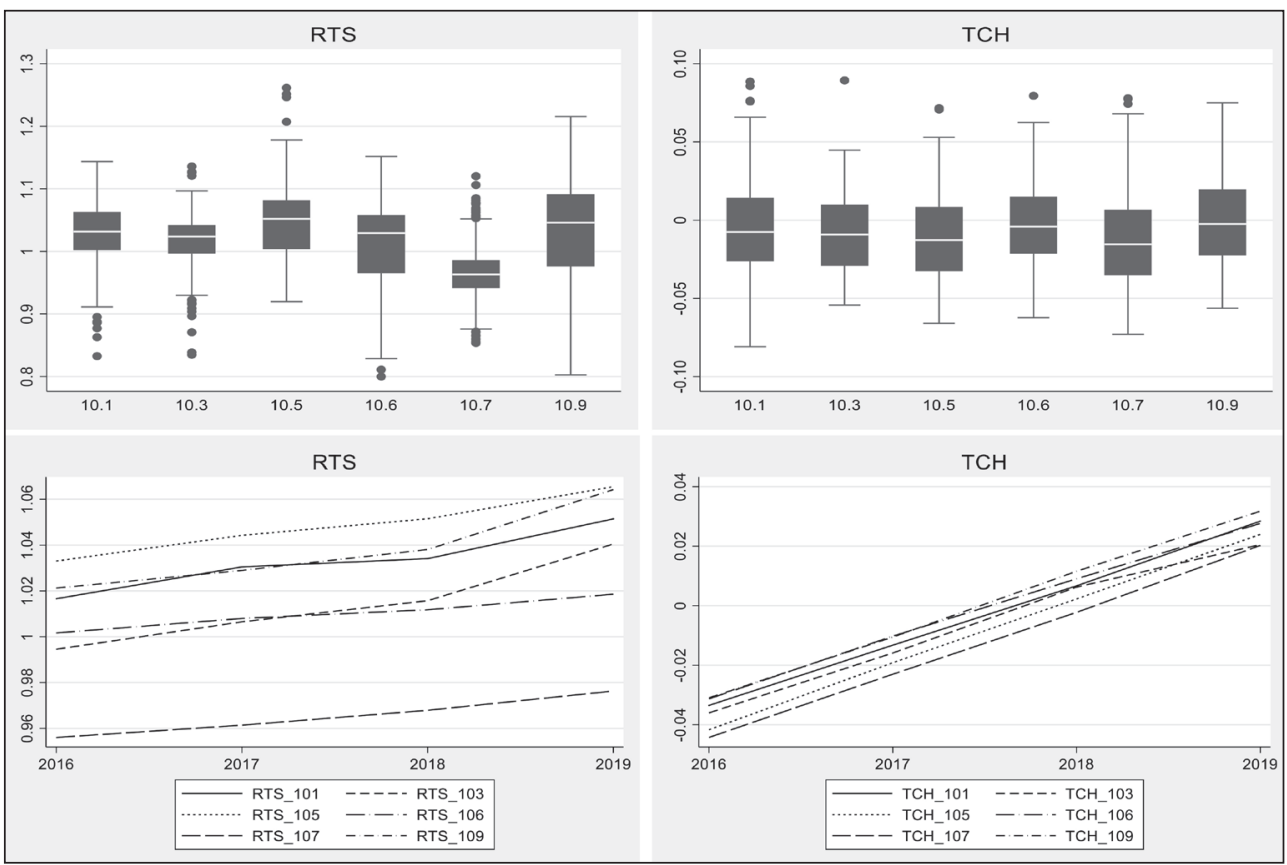

Source: own

optimal scale. This holds for all investigated NACE sub-sectors except for NACE 10.7 where the shift to the optimal scale of operation is revealed. These results foreshadow potential gains of productivity due to the scale effect in NACE 10.7, but a loss in the rest of investigated food processing sub-sectors.

Productivity and thus the competitiveness of food processors can be strengthened by technological progress. However, according to Tab. 3, the food production in the analysed period exhibited technological regress, connected with the cost increase, evaluated on the sample mean. Focus on the development of technological change $(\mathrm{TCH})$, the second-order time parameter $\left(\delta_{t t}\right)$ indicates that the cost change decelerates over time $\left(\delta_{t t}>0\right)$, see Tab. A1 in Annex. Moreover, the change from technological regress to technological progress can be seen in all investigated sub-sectors, see Fig. 1.

The box plots in Fig. 1 present the existence of inter- and intra-heterogeneity in technological change. However, differences regarding technological change among the sub-sectors are less pronounced than in the case of returns to scale. The development of technological change presented in Fig. 1 reveals that companies in NACE 10.7 faced a deeper and longer technological regress, counteracting productivity growth than in other sub-sectors. On the other hand, producers in NACE 10.9 firstly exhibited the transition from technological regress to progress in the analysed time. Moreover, the highest mean value of technological change points out that feed processors benefited by the higher positive contribution of the technological change to productivity growth compare to the rest of sub-sectors. This can be proved also with technological change component of productivity growth calculated based on Bokusheva and Čechura (2017).

Tab. 3 provides also descriptive statistics of the overall technical efficiency for the whole sample. The average overall technical efficiency is $83.4 \%$. That is, companies in investigated NACE sub-sectors can reduce their cost by $16.6 \%$, evaluated on the sample 


\section{Fig. 2: Distribution and development of technical efficiency}

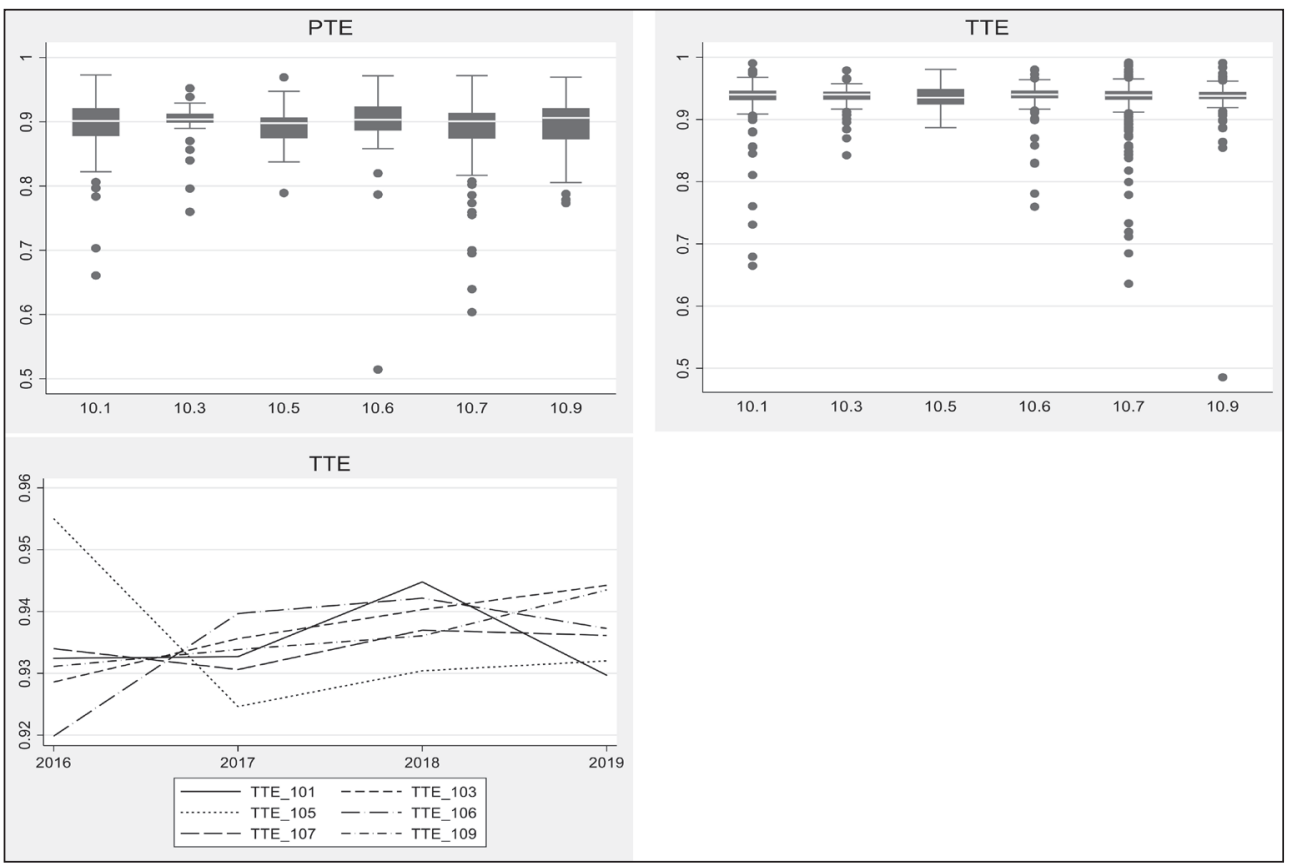

Source: own

mean. With respect to the distribution of persistent (PTE) and transient (TTE) technical efficiency, $75 \%$ of the food processors have overall technical efficiency higher than $81.9 \%$ and $25 \%$ higher than $86.3 \%$. With the average sample score of $93.5 \%$, the transient technical efficiency is higher than the persistent one and exhibits lower variability. This holds also for all investigated NACE sub-sectors, see Fig. 2.

Fig. 2 also presents the similarities of investigated sub-sectors in the mean value of both transient and persistent technical efficiencies. In other words, there are no considerable differences in technical efficiency among analysed sub-sectors. However, differences can be observed intra-sectorally. The highest variability is revealed in NACE 10.6 in terms of persistent technical efficiency. The outliers in Fig. 2 suggest that few companies in all investigated sub-sectors have systematically lagged behind the best practice. It can therefore be assumed that there will be structural changes in these sub-sectors associated with the reallocation of resources. It is worth to mention that the lowest number of outliers is in the NACE 10.5, hence it can be assumed that there exist strongly competing players in the dairy processing industry. Contrary, in the NACE 10.3, the number of outliers compared to the number of firms in the sample (see Tab. 1) presumes the presence of a non-competitive environment (Badunenko \& Kumbhakar, 2016) where can survive inefficient firms for a longer time.

When focusing on transient technical efficiency, idiosyncratic development can be observed in the analysed period. Although the contribution of technical efficiency to productivity change is positive in almost all analysed subsectors, see Fig. 2. In particular, in NACE 10.3 the technical efficiency contributed more considerable to productivity growth compared to the rest of sub-sectors. This can be also confirmed by technical efficiency change component of productivity growth calculated based on Bokusheva and Čechura (2017).

Technical, scale, and allocative efficiency are prerequisites for profitability. Due to the 


\section{Business Administration and Management}

absence of price information, it is not possible to determine the allocation efficiency and thus this study focuses only on technical and scale efficiency and its relation to profitability employing Spearman's correlation coefficient, which is robust to outliers and generally deviations from normality found out by the Shapiro-Wilk W-test. The results of the correlation analysis for the entire data set reveal at $5 \%$ level of significance that returns to scale do not correlate linearly with ROS and ROC, and between RTS and ROA is a very weak correlation (0.072). Further, a statistically significant negative correlation, but very weak, is found between technological change and ROS (-0.072) and ROA (-0.119). The medium positive correlation at $5 \%$ level of significance is found between overall technical efficiency and all profitability indicators (ROS: 0.430 ; ROA: 0.429; ROC: 0.443 ). For this reason, only the

\section{Tab. 4: Return on sales, Return on assets and Return on costs}

\begin{tabular}{c|c|c|c|c} 
NACE & ROS & ROA & ROC & Technical efficiency \\
\hline 10.1 & 1.665 & 6.294 & 2.691 & 0.837 \\
\hline 10.3 & 0.712 & 3.166 & 2.160 & 0.842 \\
\hline 10.5 & 3.262 & 9.519 & 5.928 & 0.834 \\
\hline 10.6 & 2.513 & 7.623 & 7.601 & 0.835 \\
\hline 10.7 & 1.902 & 5.185 & 4.569 & 0.830 \\
\hline 10.9 & 2.664 & 5.893 & 4.543 & 0.836 \\
\hline
\end{tabular}

\section{Fig. 3: Distribution of profitability measures}

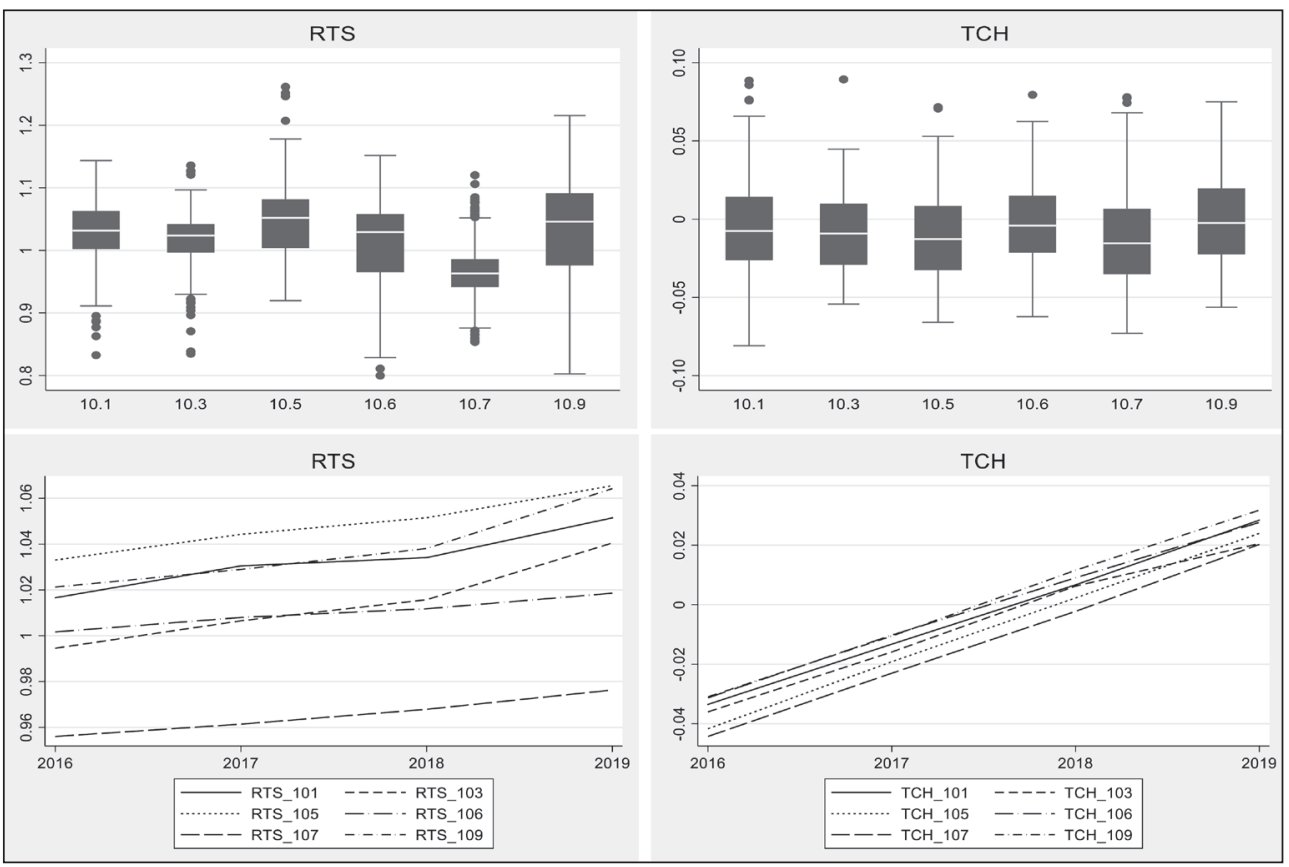

Source: own 
relationship between profitability and overall technical efficiency will be further examined, first at the level of individual NACE sub-sectors and then within these individual sub-sectors, because previous analysis of technical efficiency revealed large intra-sectoral differences, as well as the distribution of profitability measures in Fig. 3.

Tab. 4 and Fig. 3 document the average values and the distribution of the three selected profitability indicators. The best economic results in terms of ROS and ROA are reported by the sector of manufacture of dairy products (NACE 10.5). In the indicator ROC, this sector achieved the second-best result in the analysed period. In terms of overall technical efficiency, this sector achieved the second-worst result in the sample. Based on the selected data set (representativeness is $85 \%$ of total sales and $83 \%$ of total personnel costs of NACE), this sector differs from other NACE sub-sectors in particular by its high concentration of production measured by the number of employees per enterprise and the average amount of assets per enterprise. This is also reflected in the highest average value of returns to scale. According to Hicks (1935), firms with higher market power can survive in the economy even if they have higher costs since they can charge prices above the marginal cost. The positive relationship between market concentration and profitability in the Czech food industry is also confirmed by Blažková and Dvouletý (2017). Blažková and Dvouletý (2017) further stated that higher market concentration is linked with the better market position of concentrated food processors relative to the retail in the Czech Republic.

On the contrary, the lowest values of all profitability indicators are achieved by the sector processing and preserving of fruit and vegetables (NACE 10.3). However, this sector achieves the highest value of overall technical efficiency. This sector (for representativeness see Tab. 1) is characterized by the lowest share of fixed assets in total assets from the investigated sectors, also the share of depreciation in total sales is the secondlowest, similarly as the estimated share of capital in total input, of observed NACE subsectors. Moreover, the positive development of technological change is, contrary to the rest of investigated NACE sub-sectors, decelerating in NACE 10.3, see Fig. 1. This may indicate insufficient capital adequacy or obsolescence of fixed assets. The performance of this sector was negatively affected by unfavourable price developments. Industrial producer prices, based on CSO data (2021) for this sector, grew at a significantly slower pace than agricultural producer prices for fruit and vegetables. This did not create a favourable situation for the implementation of further investments that would be necessary for this sector. From the point of view of the competitiveness of this sector, the technological modernization conditioned by the favourable market situation will be important.

Based on the ROS and ROC indicator, meat processors (NACE 10.1) faced problems with monetizing their production in analysed period. This sector can be described by a high share of fixed assets in the structure of total assets, also with a higher share of depreciation in total sales, and at the same time high indebtedness, which is associated with financial costs. This is reflected in the lower value of the ROS indicator (compared to the ROA, which is based on EBIT). The negative effect between profitability and indebtedness of enterprises in the Czech food industry was found in the research of Blažková and Dvouletý $(2017,2019)$. However, this fact (which is similarly as the acceleration of positive technological change observable at the end of the analysed period, see Fig. 1), may signal the modernization or innovation of processing capacities, which is usually connected with the increased capital needs. In terms of overall technical efficiency, this sector reaches the second-highest value. It turns out that it is not a problem to produce efficiently but to sell. Blažková and Dvouletý (2019) found this sector as the least profitable and mentioned that this sector is characterized by a large number of very small processors, a broad range of production, laboriousness, and worsening situation of domestic processors owing to the increased imports.

Each NACE sub-sector of the food industry is specific and the profitability of businesses within these subgroups has been affected by different factors. Therefore, the relationship between profitability and technical efficiency must be assessed within individual sub-sectors. In addition, as mentioned above, there are differences in overall technical efficiency and profitability within these particular sectors. 


\begin{tabular}{|c|c|c|c|c|c|c|c|c|c|}
\hline Tab. 5: & $\begin{array}{l}\text { ove } \\
\text { its }\end{array}$ & $\begin{array}{l}\text { echn } \\
\text { latio }\end{array}$ & I effic & $y$ ac & ing & lect & ofita & ind & ors \\
\hline \multirow{2}{*}{$\begin{array}{c}\text { NACE } \\
\text { subgroups }\end{array}$} & \multicolumn{3}{|c|}{ ROS } & \multicolumn{3}{|c|}{ ROA } & \multicolumn{3}{|c|}{ ROC } \\
\hline & $1^{\text {st }} \mathbf{Q}$ & $3^{\text {st }} \mathbf{Q}$ & $\begin{array}{c}\text { Correl. } \\
\text { coef. }\end{array}$ & $1^{\text {st }} \mathrm{Q}$ & $3^{\text {st }} \mathbf{Q}$ & $\begin{array}{c}\text { Correl. } \\
\text { coef. }\end{array}$ & $1^{\text {st }} Q$ & $3^{\text {st }} \mathbf{Q}$ & $\begin{array}{c}\text { Correl. } \\
\text { coef. }\end{array}$ \\
\hline OTE - 10.1 & 0.825 & 0.848 & $0.261^{*}$ & 0.819 & 0.861 & $0.451^{*}$ & 0.826 & 0.851 & $0.344^{*}$ \\
\hline OTE - 10.3 & 0.812 & 0.854 & $0.372^{*}$ & 0.816 & 0.854 & $0.407^{*}$ & 0.810 & 0.852 & $0.350^{*}$ \\
\hline OTE - 10.5 & 0.822 & 0.862 & $0.509^{*}$ & 0.821 & 0.857 & $0.457^{*}$ & 0.823 & 0.864 & $0.503^{*}$ \\
\hline OTE - 10.6 & 0.781 & 0.882 & $0.658^{*}$ & 0.781 & 0.883 & $0.642^{*}$ & 0.802 & 0.860 & $0.654^{*}$ \\
\hline OTE - 10.7 & 0.805 & 0.854 & $0.514^{*}$ & 0.805 & 0.853 & $0.434^{*}$ & 0.806 & 0.856 & $0.518^{*}$ \\
\hline OTE - 10.9 & 0.828 & 0.865 & $0.350^{*}$ & 0.822 & 0.862 & $0.344^{*}$ & 0.826 & 0.864 & $0.359^{*}$ \\
\hline
\end{tabular}

Tab. 5 shows that the companies that achieve higher profitability $\left(3^{\text {st }} Q\right)$ measured by the ROS, ROA, and ROC also show higher average values of overall technical efficiency in comparison to the companies with worse results $\left(1^{\text {st }} \mathrm{Q}\right)$. This holds to all investigated NACE subsectors. However, the correlation, expressed by the Spearman's correlation coefficient, varies considerably from one sector to another.

These results are in line with Čechura (2014), who stated that if a company is not technically and/or scale efficient, then it cannot be economically efficient, since its average costs are higher compared to more efficient producers. However, these results suggest that the degree of dependence varies considerably between NACE sub-sectors in the sample. And it can be stated that in some sub-sectors, especially factors other than the company's ability to produce efficiently play a crucial role in influencing economic performance. These are, in particular, meat processors (NACE 10.1), fruit and vegetable processors (NACE 10.3) and animal feeds producers (NACE 10.9). The best $\left(3^{\text {st }} \mathrm{Q}\right.$ ) compared to the worst $\left(1^{\text {st }} Q\right)$, especially in the case of NACE 10.3., differs by the concentration of production and the size of value-added per worker in comparison to other sectors.

Moreover, these sub-sectors mainly process outputs (in case NACE 10.1 and 10.3) from the so-called sensitive sectors of primary agricultural production, which are the sectors with the lowest national self-sufficiency and thus the highest level of imports. These primary producers, which are under significant pressure to reduce costs, are subsidized from national sources within the so-called sensitive commodities or their inclusion among these commodities is being considered (pig and poultry). For food industry companies, it means higher usage of raw materials, which are not produced in the Czech Republic, as well as higher imports of products with higher added value at various stages of finalization. In the case of feed producers (NACE 10.9), on the other hand, the output of this sector is the input of these sensitive sectors, because the majority of buyers of feed mixtures are breeders of monogastric animals, i.e. pigs, and poultry.

\section{Conclusions}

The main aim of this paper was to evaluate the technical and scale efficiency and technological change of the Czech food industry and examine if these drivers of competitiveness are also translated into higher profitability. The analysis was based on microeconomic data obtained from the database Bisnode Albertina in the period from 2016 to 2019 . Attention was focused on six selected NACE sub-sectors, which together represent $74 \%$ of total turnovers of the food processing industry in the Czech Republic.

The investigation of the competitiveness drivers was based on the stochastic frontier analysis. We employed the input distance function in the specification of the Generalized True Random Effect model. Moreover, to provide a robust estimate of this model, we employed the methods which control for the potential endogeneity of netputs in the four-step estimation procedure. The main contribution of this paper is the empirical application of the recently developed approaches to robust 
efficiency and technological change analysis of the Czech food processing companies and analysation of obtained results in relation to profitability, that fulfils the gap in efficiency and profitability analysis in economic research.

The results pointed out that the average company in the sample operated at the optimal scale in the analysed period. However, the intraand inter-sectoral differences were revealed. All investigated NACE sub-sectors exhibited prevailing technological regress in the analysed period, connected with the cost increase. However, the change from technological regress to technological progress can be seen in all investigated sub-sectors compensating the move away from the optimal scale which was revealed in almost all NACE sub-sectors (NACE 10.7 is the exception). Furthermore, the results pointed out that the average food processing company could reduce its cost by $16.6 \%$ by the movement to the frontier. Focus on analysed sub-sectors, the highest average value of the overall technical efficiency was found in NACE 10.3 and the lowest in NACE 10.7. The analysis of technical efficiency dynamics pointed out that the investigated sub-sectors, except of NACE 10.7, increased the efficiency of input use and thus their competitiveness in the analysed period. The most considerable increase was revealed in NACE 10.3. Thus technical efficiency change, similarly to technological change, contributed positively to productivity and competitiveness development of the food processing industry in the analysed period. These findings have direct political implications thus to support the productivity and competitiveness of food producers, policymakers should focus on efficiency of input use and innovations that can be also the source of technical efficiency increase.

The relationship between technical and scale efficiency, technological change and profitability was evaluated by correlation analysis in the whole dataset. The analysis did not find a statistically significant correlation between return to scale, technological change, and profitability indicators or the correlation was very weak. However, the analysis revealed a medium correlation between technical efficiency and all profitability indicators for the whole dataset, but the ability to produce efficiently (using the minimum quantity of inputs) is in particular sub-sectors reflected in profitability to varying degrees. The lower correlation was found in the NACE 10.1, 10.3, and 10.9, which are sectors linked to the so-called sensitive sectors of agricultural production (either processing their inputs in case of NACE 10.1 and NACE 10.3 or supplying their outputs to these sectors in case of NACE 10.9). The sensitive sectors of agricultural production are the sectors with the lowest national self-sufficiency and thus the highest level of imports and the primary producers, as well as food producers, have been facing strong competition for a long time, which leads to significant pressure to reduce costs. Thus, it turns out that although on average these sub-sectors of food production (NACE $10.1,10.3$, and 10.9) achieved the highest technical efficiency (perhaps due to intense pressure to reduce costs) of all investigated sub-sectors, this efficiency was not translated into profitability to such an extent as in the case of milk processors (NACE 10.5), mills (NACE 10.6) and bakeries (NACE 10.7).

These findings open up space for debate on some form of intervention for these sectors. Continued support for sensitive commodities and the inclusion of other necessary livestock sectors among these commodities will be crucial. It is important to stop the decline in self-sufficiency in these commodities. For food producers will be important further investment supports in production technology (e.g. modernization of storage and processing capacities in NACE 10.3) or supports for the production of higher added value. Given that quotas for domestic food in retail do not seem to be a real tool in the context of the single European market, more effective consumer marketing will be the key to supporting domestic processors.

This analysis may also be useful in the case of examining the effects of the coronavirus crisis on the Czech food industry. The food industry is generally more dependent on the labour force compared to other sectors of the manufacturing industry (see Hedvičáková \& Král, 2021), while some sectors (especially NACE 10.1 and 10.3) suffer from a lack of workers for a long time (in addition problems with employing the foreign workers during the pandemic), there is higher dependence on imports of inputs (from observed sectors especially in NACE 10.1 and 10.3) and the economic performance of the food sector is also influenced by the tourism, gastronomy and catering sector. All mentioned 
above will affect the economic performance of food industry companies. And just in sub-sectors such as NACE 10.1, 10.3, and 10.9, that means in the sub-sectors, where efficient production is not so much reflected in the profitability, these effects can be exacerbated. The coronavirus crisis could then play a role as a catalyst that will increase domestic self-sufficiency and strengthen production and processing in our market. The role of the coronavirus crisis would be the object of the analysis in future research, which should also take into account the other determinants of profitability.

Acknowledgments: The work was supported by the internal project "SPEV - Economic Impacts under the Industry 4.0/Society 5.0 Concept", 2020, University of Hradec Králové, Faculty of Informatics and Management, Czech Republic.

\section{References}

Allendorf, J., \& Hirsch, S. (2015). Dynamic productivity growth in the European food processing industry. In Proceedings of 55th Annual Conference of German Association of Agricultural Economists (GEWISOLA). September 23-25, 2015, Giessen, Germany.

Badunenko, O., \& Kumbhakar, S. C. (2016). When, where and how to estimate persistent and transient efficiency in stochastic frontier panel data models. European Journal of Operational Research, 255(1), 272-287. https://doi.org/10.1016/j.ejor.2016.04.049

Baležentis, T., \& Sun, K. (2020). Measurement of technical inefficiency and total factor productivity growth: A semiparametric stochastic input distance frontier approach and the case of Lithuanian dairy farms. European Journal of Operational Research, 285(3), 11741188. https://doi.org/10.1016/j.ejor.2020.02.032

Baráth, L., \& Fertő, I. (2015). Heterogeneous technology, scale of land use and technical efficiency: The case of Hungarian crop farms. Land Use Policy, 42, 141-150. https://doi. org/10.1016/j.landusepol.2014.07.015

Baumol, W. J., Panzar, J. C., \& Willig, R. D. (1982). Contestable Markets and the Theory of Industry Structure. New York, NY: Harcourt Brace Jovanovich.

Blažková, I., \& Dvouletý, O. (2017). Drivers of ROE and ROA in the Czech food industry in the context of market concentration. Agris Online Papers in Economics and Informatics, 9(3), 3-13. https://doi.org/10.7160/aol.2017.090301
Blažková, I., \& Dvouletý, O. (2019). Investigating the differences in entrepreneurial success through the firm-specific factors: Microeconomic evidence from the Czech food industry. Journal of Entrepreneurship in Emerging Economies, 11(2), 154-176. https:// doi.org/10.1108/JEEE-11-2017-0093

Bokusheva, B., \& Čechura, L. (2017). Evaluating dynamics, sources and drivers of productivity growth at the farm level (Food, Agriculture and Fisheries Papers, No. 106). Paris: OECD Publishing. https://doi. org/10.1787/5f2d0601-en

Caves, D. W., Christensen, L. R., \& Diewert, W. E. (1982). The Economic Theory of Index Numbers and the Measurement of Input, Output, and Productivity. Econometrica, 50(6), 1393-1414. https://doi.org/10.2307/1913388

Czech Statistical Office. (2021). Prices of producers - time series. Retrieved April 1, 2021, from https://www.czso.cz/csu/czso/ipc_cr

Čechura, L., \& Hockmann, H. (2010). Sources of economical growth in the Czech food processing. Prague Economic Papers, 19(2), 169-182. https://doi.org/10.18267/j. pep.370

Čechura, L. (2014). Analysis of the Technical and Scale Efficiency of Farms Operating in LFA. Agris on-line Papers in Economics and Informatics, 6(4), 33-44. https://doi. org/10.22004/ag.econ.196526

Čechura, L., Hockmann, H., \& Kroupová, Z. (2014). Productivity and Efficiency of European Food Processing Industry (Compete Working Paper N7). Halle: Leibniz Institute of Agricultural Development in Transition economies (IAMO). Retrieved February 20, 2021, from http://www.iamo.de/fileadmin/ compete/files/working_paper/COMPETE_ Working_Paper_7_Productivity_FP.pdf

Čechura, L., \& Malá, Z. (2014). Technology and Efficiency Comparison of Czech and Slovak Processing Companies. Procedia Economics and Finance, 12, 93-102. https:// doi.org/10.1016/S2212-5671(14)00324-4

Čechura, L., \& Hockmann, H. (2017). Heterogeneity in Production Structures and Efficiency: An Analysis of the Czech Food Processing Industry. Pacific Economic Review, 22(4), 702-719. https://doi.org/10.1111/14680106.12217

Čechura, L., \& Žáková Kroupová, Z. (2021). Technical Efficiency in the European Dairy Industry: Can We Observe Systematic Failures 
in the Efficiency of Input Use? Sustainability, 13(4), $1830 . \quad$ https://doi.org/10.3390/ su13041830

Gschwandtner, A., \& Hirsch, S. (2018). What Drives Firm Profitability? A Comparison of the US and EU Food Processing Industry. The Manchester School, 86(3), 390-416. https://doi.org/10.1111/manc.12201

Hirsch, S., Schiefer, J., Gschwandtner, A., \& Hartmann, M. (2014). The determinants of firm profitability differences in EU food processing. Journal of Agricultural Economics, 65(3), 703-721. https://doi.org/10.1111/1477-9552.12061

Hirsch, S., \& Schiefer, J. (2016). What Causes Firm Profitability Variation in the EU Food Industry? ARedux of Classical Approaches of Variance Decomposition. Agribusiness, 32(1), 79-92. https://doi.org/10.1002/agr.21430

Chambers, R. G. (1988). Applied Production Analysis: A Dual Approach. Cambridge: Cambridge University Press.

Chirinko, R. S., \& Fazzari, S. M. (1994). Economic fluctuations, market power, and returns to scale: Evidence from firm level data. Journal of Applied Econometrics, 9(1), 47-69. https://doi.org/10.1002/jae.3950090105

Coelli, T., \& Perelman, S. (2000). Technical Efficiency of European Railways: A Distance Function Approach. Applied Economics, 32(15), 1967-1976. https://doi. org/10.1080/00036840050155896

Dimara, E., Skuras, D., Tsekouras, K., \& Tzelepis, D. (2008). Productive efficiency and firm exit in the food sector. Food Policy, 33(2), 185-196. https://doi.org/10.1016/j. foodpol.2007.08.003

Farrell, M. J. (1957). The Measurement of Productive Efficiency. Journal of the Royal Statistical Society, 120(3), 253-290. https://doi. org/10.2307/2343100

Filippini, M., \& Greene, W. H. (2016). Persistent and Transient Productive Inefficiency: A Maximum Simulated Likelihood Approach. Journal of Productivity Analysis, 45(2), 187-196. https://doi.org/10.1007/s11123-015-0446-y

Gordon, M., \& Davidova, S. (2004). Farm productivity and efficiency in the CEE applicant countries: a synthesis of results. Agricultural Economics, 30(1), 1-16. https://doi. org/10.1111/j.1574-0862.2004.tb00172.x

Gumbau-Albert, M., \& Maudos, J. (2002). The determinants of efficiency: the case of the Spanish industry. Applied Economics, 34(15), 1941-1948. https://doi.org/10.1080/00036840210127213
Hailu, A., \& Veeman, T. S. (2000). Environmentally Sensitive Productivity Analysis of the Canadian Pulp and Paper Industry, 1959-1994: An Input Distance Function Approach. Journal of Environmental Economics and Management, 40(3), 251-274. https://doi. org/10.1006/jeem.2000.1124

Hedvičáková, M., \& Král, M. (2021). Performance Evaluation Framework under the Influence of Industry 4.0: The Case of the Czech Manufacturing Industry. E\&M Economics and Management, 24(1), 118-134. https://doi. org/10.15240/tul/001/2021-1-008

Irz, X., \& Thirtle, C. (2005). Dual Technological Development in Botswana Agriculture: A Stochastic Input Distance Function Approach. Journal of Agricultural Economics, 55(3), 455-478. https://doi. org/10.1111/j.1477-9552.2004.tb00110.x

Kapelko, M. (2019). Measuring productivity change accounting for adjustment costs: evidence from the food industry in the European Union. Annals of Operations Research, 278(1), 215-234. https://doi.org/10.1007/s10479-017-2497-0

Karagiannis, G., Midmore, P., \& Tzouvelekas, V. (2004). Parametric Decomposition of Output Growth Using a Stochastic Input Distance Function. American Journal of Agricultural Economics, 86(4), 1044-1057. https://doi. org/10.1111/j.0002-9092.2004.00652.x

Keramidou, I., Mimis, A., Fotinopoulou, A., \& Tassis, C. D. (2013). Exploring the relationship between efficiency and profitability. Benchmarking: An International Journal, 20(5), 647-660. https://doi.org/10.1108/BIJ-12-2011-0090

Kounetas, K., \& Tsekouras, K. (2007). Measuring Scale Efficiency Change Using a Translog Distance Function. International Journal of Business and Economics, 6(1), 63-69.

Kumar, S. (2008). An Analysis of EfficiencyProfitability Relationship in Indian Public Sector Banks. Global Business Review, 9(1), 115-129. https://doi.org/10.1177/097215090700900108

Kumbhakar, S. C., \& Knox Lovell, C. A. (2000). Stochastic Frontier Analysis. Cambridge: Cambridge University Press. https://doi.org/10.1017/CBO9781139174411

Kumbhakar, S. C., Orea, L., RodriguezÁlvarez, A., \& Tsionas, E. G. (2007). Do we estimate an input or an output distance function? An application of the mixture approach to European railways. Journal of Productivity Analysis, 27(2), 87-100. https://doi.org/10.1007/s11123-006-0031-5 
Kumbhakar, S. C., \& Tsionas, E. G. (2012). Firm heterogeneity, persistent and transient technical inefficiency: a generalized true random effects model. Journal of Applied Econometrics, 29(1), 110-132. https://doi. org/10.1002/jae.2300

Kumbhakar, S. C., \& Lien, G. (2009). Productivity and profitability decomposition: A parametric distance function approach. Acta Agriculturae Scandinavica, Section C - Food Economics, 6(3-4), 143-155. https://doi.org/10 $.1080 / 16507541.2010 .481898$

Kumbhakar, S. C., Lien, G., \& Hardaker, J. B. (2014). Technical efficiency in competing panel data models: A study of Norwegian grain farming. Journal of Productivity Analysis, 41(2), 321-337, https://doi.org/10.1007/s11123-012-0303-1

Latruffe, L. (2010). Competitiveness, Productivity and Efficiency in the Agricultural and Agri-Food Sectors (OECD Food, Agriculture and Fisheries Papers, No. 30). Paris: OECD Publishing. https://doi. org/10.1787/5km91nkdt6d6-en

Lien, G., Kumbhakar, S. C., \& Alem, H. (2018). Endogeneity, heterodeneity, and determinants of inefficiency in Norwegian crop-producing farms. International Journal of Production Economics, 201, 53-61. https://doi. org/10.1016/j.ijpe.2018.04.023

Mathijs, E., \& Vranken, L. (2000). Farm restructuring and efficiency in transition: evidence from Bulgaria and Hungary. Paper presented at the American Agricultural Economics Association Annual Meeting, Tampa, FL, USA, July 30-August 2. https://doi. org/10.22004/ag.econ.21886

Mezera, J., Plášil, M., \& Náglová, Z. (2019). Panorama potravinárského prümyslu 2019 [Panorama of the Food industry 2019]. Prague: Ministry of Agriculture of the Czech Republic.

Morroni, M. (2006). Knowledge, Scale and Transactions in the Theory of the Firm. Cambridge: Cambridge University Press. https://doi.org/10.1017/CBO9780511617232

Ministry of Industry and Trade. (2019). Panorama zpracovatelského průmyslu ČR 2018 [Panorama of the Manufacturing Industry 2018]. Retrieved April, 2021, from https://www.mpo.cz/ cz/prumysl/zpracovatelsky-prumysl/panoramazpracovatelskeho-prumyslu/-panoramazpracovatelskeho-prumyslu-cr-2018--249524/

Njuki, E., \& Bravo-Ureta, B. E. (2015). The Economic Costs of Environmental Regulation in U.S. Dairy Farming: A Directional Distance
Function Approach. American Journal of Agricultural Economics, 97(4), 1087-1106. https://doi.org/10.1093/ajae/aav007

Roodman, D. (2009). How to do Xtabond2: An Introduction to Difference and System GMM in Stata. Stata Journal, 9(1), 86-136. https://doi.org/10.1177/1536867X0900900106

Rudinskaya, T., \& Kuzmenko, E. (2019). Investments, Technical Change and Efficiency: Empirical Evidence from Czech Food Processing. Agris on-line Papers in Economics and Informatics, 11(4), 93-103. https://doi. org/10.7160/aol.2019.110409

Rudinskaya, T., \& Náglová, Z. (2018). Impact of Subsidies on Technical Efficiency of Meat Processing Companies. AGRIS on-line Papers in Economics and Informatics, 10(1), 61-70. https://doi.org/10.7160/aol.2018.100106

Shephard, R. W. (1970). Theory of Cost and Production Functions. Princeton: Princeton University Press.

Singbo, A., \& Larue, B. (2016). Scale Economies, Technical Efficiency, and the Sources of Total Factor Productivity Growth of Quebec Dairy Farms. Canadian Journal of Agricultural Economics/Revue Canadienne D’agroéconomie, 64(2), 339-363. https://doi. org/10.1111/cjag.12077

Soboh, R. A. M. E., Oude Lansink, A., \& Van Dijk, G. (2014). Efficiency of European Dairy Processing Firm. NJAS - Wageningen Journal of Life Sciences, 70-71, 53-59. https://doi. org/10.1016/j.njas.2014.05.003

Tsionas, E. G., Kumbhakar, S. C., \& Malikov, E. (2015). Estimation of Input Distance Functions: A System Approach. American Journal of Agricultural Economics, 97(5), 14781493. https://doi.org/10.1093/ajae/aav012

Ullah, S., Akhtar, P., \& Zaefarian, G. (2018). Dealing with endogeneity bias: The generalized method of moments (GMM) for panel data. Industrial Marketing Management, 71, 69-78. https://doi.org/10.1016/j.indmarman.2017.11.010

Vokoun, M., Polanecký, L., \& Stellner, F. (2015). The impact of the recent economic crisis on the food industry in the Czech and Slovak Republic. Procedia Economics and Finance, 34(3), 142-148. https://doi.org/10.1016/S22125671(15)01612-3

Zelenyuk, V. (2015). Aggregation of scale efficiency. European Journal of Operational Research, 240(1), 269-277. https://doi. org/10.1016/j.ejor.2014.06.038 


\section{Annex:}

\section{Tab. A1: The IDF estimates}

\begin{tabular}{l|c|c|c}
\multicolumn{1}{r|}{ In_xC } & Coef. & Std. err. & P>|t| \\
\hline In_y & -0.999 & 0.021 & 0.000 \\
\hline In_xL & 0.211 & 0.027 & 0.000 \\
\hline In_xM & 0.729 & 0.023 & 0.000 \\
\hline $\mathrm{t}$ & 0.009 & 0.004 & 0.028 \\
\hline In_y_2 & 0.013 & 0.032 & 0.696 \\
\hline In_xL_2 & 0.112 & 0.049 & 0.021 \\
\hline In_xM_2 & -0.001 & 0.123 & 0.990 \\
\hline In_yxL & -0.039 & 0.020 & 0.045 \\
\hline In_yxM & 0.054 & 0.047 & 0.254 \\
\hline In_xLxM & -0.039 & 0.072 & 0.590 \\
\hline t_2 & -0.021 & 0.004 & 0.000 \\
\hline In_yt & 0.008 & 0.004 & 0.028 \\
\hline In_xLt & 0.019 & 0.006 & 0.004 \\
\hline In_xMt & -0.011 & 0.005 & 0.052 \\
\hline _cons & -0.102 & 0.054 & 0.059 \\
\hline Tests & & & P-value \\
\hline F-test & $8,809.360$ & F[14,467] & 0.000 \\
\hline AR(2) & -1.070 & & 0.286 \\
\hline
\end{tabular}

Source: own 